\title{
REMOVAL OF HYDROGEN SULPHIDE CONTENT FROM BIOGAS BY ATOMIZING OF ALKALI SOLUTION
}

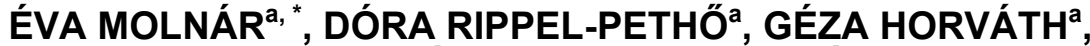 \\ JANKA BOBEK ${ }^{\mathrm{a}}$, RÓBERT BOCSI ${ }^{\mathrm{a}}$, ZOLTÁN HODAl $^{\mathrm{a}}$
}

\begin{abstract}
Our energy requirements increased significant in the last decades. For this reason the potential utilization of renewable energy sources come into view. Biogas is a kind of renewable energy sources. Purification of raw biogas is essential prior to use. Mainly the hydrogen sulfide content of gas is very harmful. It can cause corrosion in compressors and engines. Furthermore sulfur dioxide and sulfur trioxide are formed from hydrogen sulfide due to combustion, which similarly corrosive present of water and toxic like hydrogen sulfide. We examined the hydrogen sulfide absorption from biogas model gas mixtures $\left(\mathrm{CO}_{2}, \mathrm{H}_{2} \mathrm{~S}, \mathrm{~N}_{2}\right)$ based on alkali competitive chemisorption technology.
\end{abstract}

Keywords: biogas, chemisorption, sodium hydroxide, hydrogen sulphide, carbon dioxide

\section{INTRODUCTION}

Renewable energy produced by biogas technology has a great potential for growth to meet our future energy demands. Furthermore the technology is instrumental in waste management [1-2]. Biogas is generated from organic materials (fats, proteins, carbohydrates) by anaerobic metabolism [1-6]. The character of the used biomass and the applied operational conditions during anaerobic digestion determine the effective composition of the gas [6]. The raw biogas consists of mainly methane $\left(\mathrm{CH}_{4}\right)$ and carbon dioxide $\left(\mathrm{CO}_{2}\right)$. Additionally small amount of ammonia $\left(\mathrm{NH}_{3}\right)$, hydrogen sulfide $\left(\mathrm{H}_{2} \mathrm{~S}\right)$, nitrogen $\left(\mathrm{N}_{2}\right)$, oxygen $\left(\mathrm{O}_{2}\right)$, carbon monoxide (CO), water $\left(\mathrm{H}_{2} \mathrm{O}\right)$, siloxanes and halogenated volatile organic compounds (VOCs) are present as impurities in biogas [2; 5-8]. Table 1 shows the chemical composition of raw biogas from different sources [7].

\footnotetext{
a Institute of Chemical and Process Engineering, Department of Chemical Engineering Science, University of Pannonia, $\mathrm{H}-8200$ Veszprém, Hungary.

Corresponding author: molnare@almos.uni-pannon.hu
} 
First of all $\mathrm{H}_{2} \mathrm{~S}$ content should be removed from the raw gas for many reasons. It can cause corrosion in compressors, gas storage and engines, in addition sulfur di- $\left(\mathrm{SO}_{2}\right)$ and trioxide $\left(\mathrm{SO}_{3}\right)$ are formed duo to combustion, which are similarly hazardous components like $\mathrm{H}_{2} \mathrm{~S}$ [1-2; 5-10].

Table 1. Chemical composition of raw biogas from different sources [7]

\begin{tabular}{|l|c|c|c|}
\hline Component & Biogas factory & Sewer factory & Garbage landfill \\
\hline $\mathbf{C H}_{4}$ [\% vol.] & $60-70$ & $55-65$ & $45-55$ \\
\hline $\mathbf{C O}_{2}[\%$ vol.] & $30-40$ & $35-45$ & $30-40$ \\
\hline $\mathbf{N}_{2}$ [\% vol.] & $<1$ & $<1$ & $5-15$ \\
\hline $\mathbf{H}_{2} \mathbf{S}$ [ppmv] & $10-2000$ & $10-40$ & $50-300$ \\
\hline $\mathbf{N H}_{3}$ [ppmv] & \multicolumn{3}{|c|}{ Trace } \\
\hline $\mathbf{C O}$ [ppmv] & Trace \\
\hline $\mathbf{O}_{2}$ [ppmv] & Trace \\
\hline $\mathbf{V O C s}$ [ppmv] & Trace \\
\hline $\mathbf{H}_{2} \mathbf{O}$ [ppmv] & Trace \\
\hline Siloxanes [ppmv] & \multicolumn{3}{|c|}{ Trace } \\
\hline
\end{tabular}

Nowadays desulfurization of biogas can be carried out in many ways, for example biological desulphurization, adsorption on impregnated activated carbon, scrubbing in aqueous sodium hydroxide $(\mathrm{NaOH})$ solution or in water $\left(\mathrm{H}_{2} \mathrm{O}\right)$, addition of iron chloride $\left(\mathrm{FeCl}_{2}\right)$ to the bioreactor, membrane separation and so on [1-3; 6-10].

In this paper we deal with $\mathrm{H}_{2} \mathrm{~S}$ chemisorption in $\mathrm{NaOH}$ solution. The reaction time of $\mathrm{CO}_{2}$ and $\mathrm{H}_{2} \mathrm{~S}$ with $\mathrm{NaOH}$ are different. $\mathrm{CO}_{2}$ reacts with $\mathrm{NaOH}$ solution more slowly than $\mathrm{H}_{2} \mathrm{~S}$ [11-13]. Based on this fact the chemisorption in $\mathrm{NaOH}$ solution is able to work as a selective method for $\mathrm{H}_{2} \mathrm{~S}$ capture, if the sufficiently short contact time $(<1 \mathrm{~s})$ is provided. The selectivity is important in order to minimize the consumption of chemicals. Besides it is necessary to ensure the large contact surface and intense contact of gas and absorbent in order that the operation achieves a relatively high efficiency $(>50 \%)$ [12; 14-16]. During the process stable and undangerous compounds are formed (Equations 1-2-3), such as sodium sulfide $\left(\mathrm{Na}_{2} \mathrm{~S}\right)$ and sodium carbonate $\left(\mathrm{Na}_{2} \mathrm{CO}_{3}\right)[15 ; 18]$.

$$
\begin{gathered}
\mathrm{NaOH}+\mathrm{H}_{2} \mathrm{~S} \rightarrow \mathrm{NaHS}+\mathrm{H}_{2} \mathrm{O} \\
2 \mathrm{NaOH}+\mathrm{H}_{2} \mathrm{~S} \rightarrow \mathrm{Na}_{2} \mathrm{~S}+2 \mathrm{H}_{2} \mathrm{O} \\
2 \mathrm{NaOH}+\mathrm{CO}_{2} \rightarrow \mathrm{Na}_{2} \mathrm{CO}_{3}+\mathrm{H}_{2} \mathrm{O}
\end{gathered}
$$

The mentioned requirement for conditions of operation cannot be achieved by using a classical packed column chemisorber [12-16]. Therefore, spray method was applied for measurements. The objective of 
this work was to study the feasibility of technique based on competitive chemisorption of $\mathrm{H}_{2} \mathrm{~S}$ and $\mathrm{CO}_{2}$ in $\mathrm{NaOH}$ fine spray for biogas purification. If the efficiency of $\mathrm{H}_{2} \mathrm{~S}$ absorption achieves at least $50 \%$ while the alkali excess is less than $10 \mathrm{~mol} \mathrm{NaOH} / \mathrm{mol} \mathrm{H}_{2} \mathrm{~S}$, we can say that the operation is economic. The primary purpose is to achieve this theoretical limit.

\section{RESULTS AND DISCUSSION}

Measurements were performed based on knowledge of general properties of biogas, results of pre-experiments and the application range of experimental apparatus. The experiences of pre-measurements were the follows: the optimal concentration of $\mathrm{NaOH}$ solution is influenced by contact time of gas and liquid phases; the molar alkali excess $\left(>1 \mathrm{~mol} \mathrm{NaOH} / \mathrm{mol} \mathrm{H}_{2} \mathrm{~S}\right)$ must be provided to achieve effective operation; increase of absorbent volumetric flow rate causes improvement of efficiency of $\mathrm{H}_{2} \mathrm{~S}$ absorption, however it is limited by the quality of atomization (drop and surface formation) and by the difference between contact time and reaction time requirement.

For the measurements 4 different gas mixture were examined. The applied experimental conditions were: 4 bar pressure; $0,4 \mathrm{Nm}^{3} / \mathrm{h}$ volumetric gas flow rate; $2 \%$ weigh $\mathrm{NaOH}$ absorbent concentration; $1-2-3-4-5 \mathrm{~cm}^{3} / \mathrm{min}$ volumetric flow rate of $\mathrm{NaOH}$ solution. The results of experiments are shown in Figures 1-3.

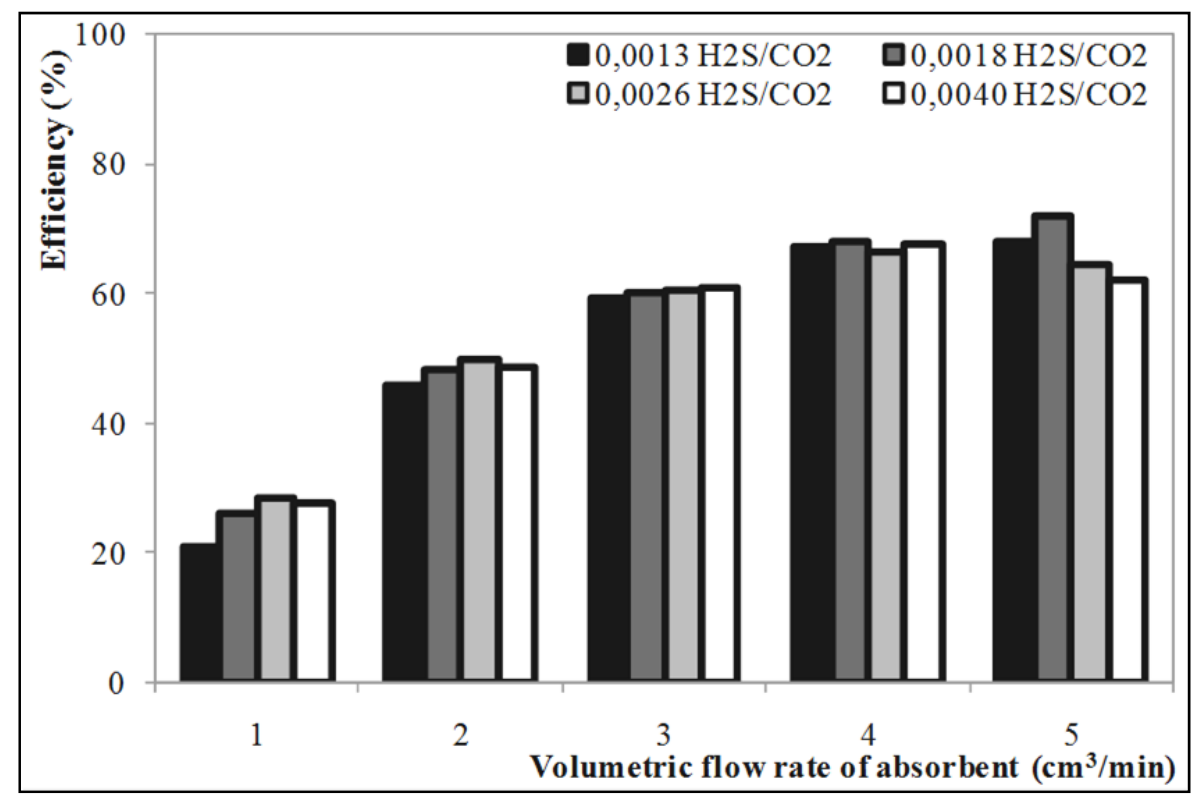

Figure 1. Efficiency of $\mathrm{H}_{2} \mathrm{~S}$ absorption as a function of absorbent flow rate 
The efficiency of absorption system modified between 20 and $72 \%$. Increase of $\mathrm{NaOH}$ solution volumetric flow rate caused improvement of efficiency of $\mathrm{H}_{2} \mathrm{~S}$ absorption, however raising from 4 to $5 \mathrm{~cm}^{3} / \mathrm{min}$ resulted in clear advance. Striking differences were not observed among the results of test series in Figure 1.

In order to see this process also by economic aspect, efficiency data were represented as a function of molar ratio of $\mathrm{NaOH}$ and $\mathrm{H}_{2} \mathrm{~S}$ (Figure 2).

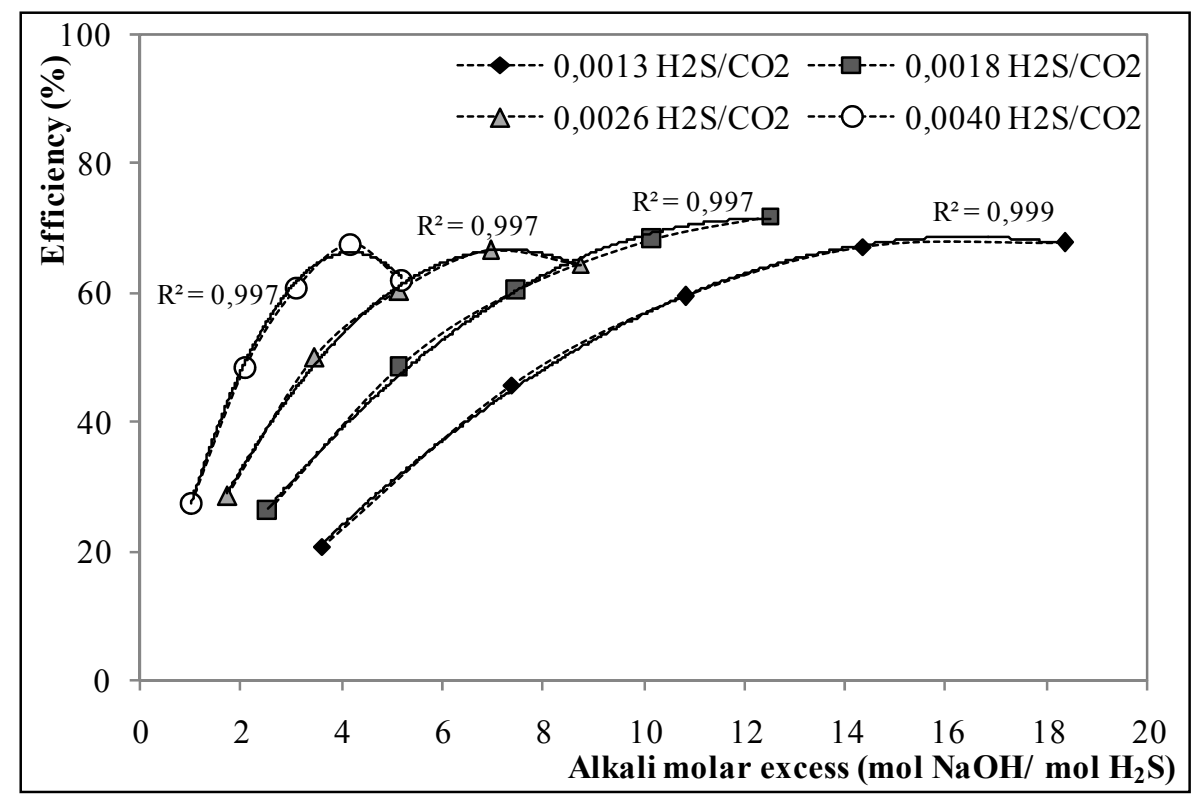

Figure 2. Efficiency of $\mathrm{H}_{2} \mathrm{~S}$ absorption as a function of alkali molar excess

The system was able to reach $50 \%$ efficiency less than $10 \mathrm{~mol}$ $\mathrm{NaOH} / \mathrm{mol} \mathrm{H}_{2} \mathrm{~S}$ alkali excess by using every gas mixture in the tested range. Namely, according to our expectations the operation was economic and efficient. Second-order polynomial curves can fit on the measuring data $\left(R^{2} \geq 0,997\right)$. The efficiency of $\mathrm{H}_{2} \mathrm{~S}$ absorption improves with increase of $\mathrm{H}_{2} \mathrm{~S} / \mathrm{CO}_{2}$ volumetric ratio. This result can be explained by change of degree of competition. If $\mathrm{H}_{2} \mathrm{~S} / \mathrm{CO}_{2}$ volumetric ratio increases, in terms of $\mathrm{H}_{2} \mathrm{~S}$ the competition will be lower. Furthermore, the probability of encounter of $\mathrm{H}_{2} \mathrm{~S}$ and $\mathrm{NaOH}$ will raise with increase of $\mathrm{H}_{2} \mathrm{~S} / \mathrm{CO}_{2}$ ratio. In contrast at the same time the probability of encounter of $\mathrm{CO}_{2}$ and $\mathrm{NaOH}$ will decrease.

Investigation of mass transfer as a function of alkali molar excess was performed as well (Figure 3). To calculate the transfer surface we had to determine the average size of droplets. We assumed Nukiyama-Tanasawa 
equation (4 Equation) is capable for this task and the formed droplets are spherical. The number of drops is given by ratio of absorbent volumetric rate and volume of average drop. The transfer surface can be defined by multiplication of quantity of drops and surface of average droplet.

$$
D_{S}=\frac{585}{U_{r}}\left(\frac{\sigma}{\rho_{L}}\right)^{0.5}+597\left[\frac{\mu_{L}}{\left(\sigma \rho_{L}\right)^{0.5}}\right]^{0.45}\left(1000 \frac{Q_{L}}{Q_{G}}\right)^{1.5}
$$

where $\sigma=$ liquid surface tension (dyne/cm); $\rho_{\mathrm{L}}=$ liquid density $\left(\mathrm{g} / \mathrm{cm}^{3}\right) ; \mu_{\mathrm{L}}=$ liquid viscosity (poise); $Q_{L}=$ liquid volume flow rate $\left(\mathrm{cm}_{3} / \mathrm{sec}\right) ; Q_{G}=$ gas volume flow rate $\left(\mathrm{cm}^{3} / \mathrm{sec}\right) ; U_{\mathrm{r}}=$ relative velocity between liquid and gas $(\mathrm{cm} / \mathrm{sec})[19]$.

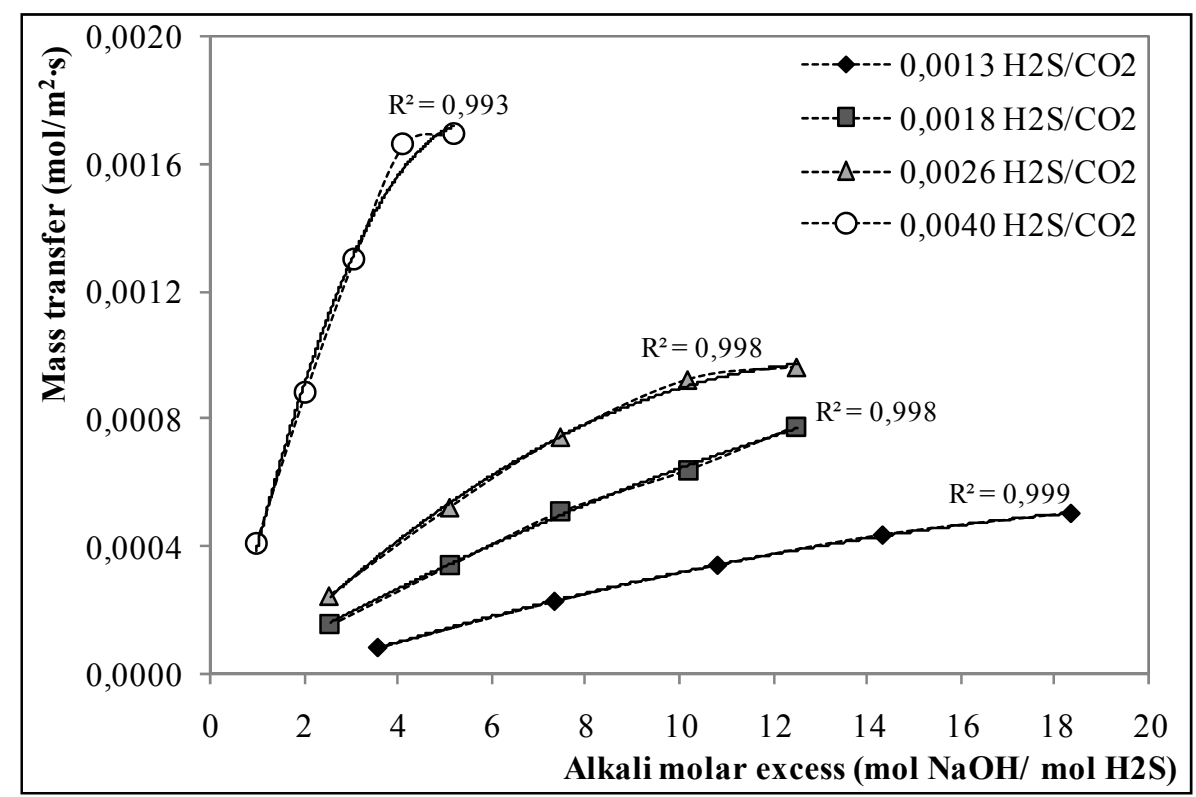

Figure 3. Change of mass transfer as a function of alkali excess

The highest gradient slope of the mass transfer curve was in the case of highest value of $\mathrm{H}_{2} \mathrm{~S} / \mathrm{CO}_{2}$ volumetric ratio as a function of $\mathrm{NaOH} / \mathrm{H}_{2} \mathrm{~S}$ molar excess. By using second-order polynomial curves we can follow the change of data series $\left(R^{2} \geq 0,993\right)$. The results can be explained also by the change of degree of competition between $\mathrm{H}_{2} \mathrm{~S}$ and $\mathrm{CO}_{2}$.

\section{CONCLUSIONS}

The described technique based on competitive chemisorption of $\mathrm{H}_{2} \mathrm{~S}$ and $\mathrm{CO}_{2}$ in $\mathrm{NaOH}$ fine spray is feasible for biogas purification. The system was able to reach $50 \%$ efficiency less than $10 \mathrm{~mol} \mathrm{NaOH} / \mathrm{mol} \mathrm{H}_{2} \mathrm{~S}$ 
alkali excess by using every gas mixture in the tested range. The results proves that increase of $\mathrm{H}_{2} \mathrm{~S} / \mathrm{CO}_{2}$ volumetric ratio have positive impact on the efficiency of $\mathrm{H}_{2} \mathrm{~S}$ absorption and the mass transfer of $\mathrm{H}_{2} \mathrm{~S}$ from gas to liquid phase. This experience can be explained by change of competition degree, and change of probability of encounter of $\mathrm{CO}_{2}$ and $\mathrm{H}_{2} \mathrm{~S}$ with $\mathrm{NaOH}$.

\section{EXPERIMENTAL SECTION}

Examinations were implemented by use three different compositions of gas mixture (Table 2).

Table 2. Composition of examined gas mixtures

\begin{tabular}{|c|c|c|c|}
\hline $\begin{array}{c}\text { Calculated } \mathbf{N}_{\mathbf{2}} \\
\text { content } \\
\text { [\% vol.] }\end{array}$ & $\begin{array}{c}\text { Measured } \mathbf{C O}_{\mathbf{2}} \\
\text { content } \\
\text { [\% vol.] }\end{array}$ & $\begin{array}{c}\text { Measured } \mathbf{H}_{\mathbf{2}} \mathbf{S} \\
\text { content } \\
\text { [ppmv] }\end{array}$ & $\begin{array}{c}\text { Volumetric ratio of } \\
\mathbf{H}_{\mathbf{2}} \mathbf{S} / \mathbf{C O}_{\mathbf{2}} \\
{[-]}\end{array}$ \\
\hline 62,9520 & 37,0 & 480 & 0,0013 \\
\hline 60,9310 & 39,0 & 690 & 0,0018 \\
\hline 60,9000 & 39,0 & 1000 & 0,0026 \\
\hline 57,4304 & 42,4 & 1696 & 0,0040 \\
\hline
\end{tabular}

Table 3 shows the parameters of operation.

Table 3. Experimental conditions

\begin{tabular}{|c|c|}
\hline Pressure [bar] & 4 \\
\hline Volumetric gas flow rate $\left[\mathrm{Nm}^{3} / \mathrm{h}\right]$ & 0,4 \\
\hline Volumetric liquid flow rate $\left[\mathrm{cm}^{3} / \mathrm{min}[\right.$ & $1-2-3-4-5$ \\
\hline Concentration of $\mathrm{NaOH}$ absorbent [\% weigh] & 2 \\
\hline Contact time [s] & 0,23 \\
\hline
\end{tabular}

The procedure is operated as follows. The $\mathrm{NaOH}$ solution is delivered by chemical feeder pump to the experimental appliance. The pre-mixed gas mixture gets into the apparatus from the gas cylinder. The liquid and gas stream encounter in reaction space immediately after the nozzle (Figure 4).

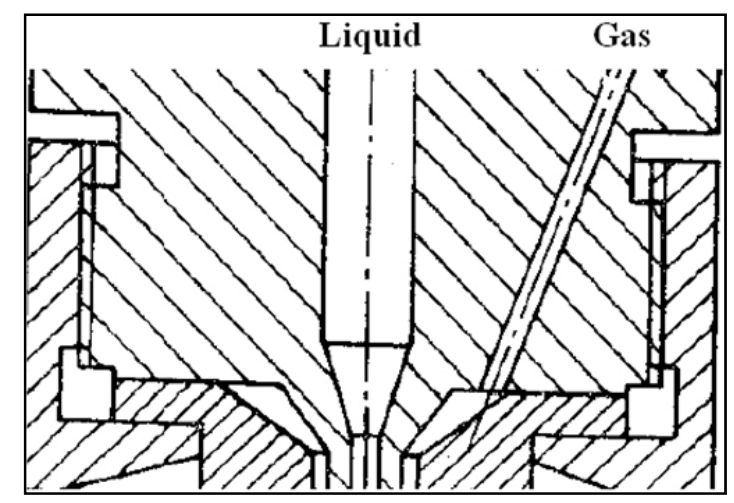

Figure 4. External mixed pneumatic liquid atomizer [20] 
The kinetic energy of the gas phase covers the energy required for atomization. After intensive contact of two different phases the phase separation is done by applying mist eliminator. The spent absorbent should be removed periodically from the separation zone by using a tap. The $\mathrm{CO}_{2}$ (\% vol.) and $\mathrm{H}_{2} \mathrm{~S}$ (ppmv) content of output purified gas is sampled continuous by applying Dräger $\mathrm{X}$-am 7000 gas analyzer [12]. This gas analyzer is able to measure the $\mathrm{H}_{2} \mathrm{~S}$ level by electrochemical sensor and the $\mathrm{CO}_{2}$ level by infrared sensor [21].

\section{ACKNOWLEDGMENTS}

We are grateful to the MOL for financial supporting this project.

\section{REFERENCES}

1. N. Tippayawong, P. Thanompongchart, Energy, 2010, 35, 4531.

2. L. Grazia, Journal of Cleaner Production, 2016, 131, 364.

3. J. Krischan, A. Makaruk, M. Harasek, Journal of Hazardous Materials, 2012, 215-216, 49.

4. S.S. Kapdi, V.K. Vijay, S.K. Rajesh, R. Prasad, Renewable Energy, 2005, 30(8), 1195.

5. S. Qie, L. Hailong, Y. Jinying, L. Longcheng, Y. Zhixin, Y. Xinhai, Renewable and Sustainable Energy Reviews, 2015, 51, 521.

6. E. Ryckebosh, M. Drouillon, H. Vervaeren, Biomass and Bioenergy, 2011, 35, 1633.

7. J. Lasocki, K. Kolodziejczyk, A. Matuszewska, Polish Journal of Environmental Studies, 2015, 24(3), 1427.

8. L. Dubois, D. Thomas, Chemical Engineering Technology, 2010, 33(10), 1601.

9. D. Panza, V. Belgiorno, Process Safety and Environmental Protection, 2010. $88,420$.

10. M. Pawlowska, M. Zdeb, A. Montusiewicz, M. Lebiocka, Environmental Protection Engineering, 2009, 35(3), 157.

11. K. T. Hsieh, R. C. Aiken, Chemical Engineering Commuication, 1988, 31, 367.

12. Á. Vágó, D. Rippel-Pethő, G. Horváth, I. Tóth, K. Oláh, Hungarian Journal of Industrial Chemistry, Veszprém, 2011, 39 (2), 283.

13. J. B. Siemak, M. Gelbs, SPE California Regional Meeting, 1985, 13650-MS

14. R. G. Heltz, Al L. Rocklin, U.S. Patent, US2747962 A, 1956.

15. V. Srinivasan, R. C. Aiken, Fuel Processing Technology, 1988, 19, 141.

16. É. Molnár, D. Rippel-Pethő, G. Horváth, Z. Hodai, R. Bocsi, J. Bobek, Periodica Polytechnica Chemical Engineering, 2016, 60(2), 74. 
É. MOLNÁR, D. RIPPEL-PETHŐ, G. HORVÁTH, J. BOBEK, R. BOCSI, Z. HODAI

17. E. Bendall, R. C. Aiken, F. Mandas, AlChE Journal, 1983, 29(1), 66.

18. A. L. Kohl, R. B. Nilsen, Gas Purification, Houston, Gulf Publishing Company, 1997.

19. D. S. F. Atkinson, W. Strauss, Journal of the Air Pollution Control Association, 1978, 28(11), 1114.

20. J. Turba, Carburators, Müszaki Könyvkiadó, Budapest, Hungary, 1976.

21. http://www.draeger.com 